Nina Pinto-Abecasis

Bar Ilan University

Salti Center for Ladino Studies

Open University, Israel
UDC 811.411.16(64)

DOI https://doi.org/10.18485/fid.2017.7.ch27

\title{
FUNCTIONALITY, MEMORY AND CULTURAL ANCHOR: BACK TO THE HAKETIA LANGUAGE
}

\begin{abstract}
У овом чланку наглашава се повратак хакетији, језику Јевреја из северног Марока, и његово коришћење у широким круговима у дискурсу као уточиште идентитета међу Јеврејима шпанског Марока. Овај повратак језику огледа се у виртуелним сферама, друштвеним мережама, друштвеним окупљањима на основу града порекла или на основу самог језика - феномен који је био реткост у прошлости. Обнова хакетије током последњих година призива „замишљену заједницу“ (Андерсон, 1991) чланова широм света, истовремено делујући као покушај да се држе фрагменти сећања на места одакле су отишли. Фокус рада је на „Haketia’suseas“ тајном језику међу Јеврејима који су живели са хришћанским говорницима кастиљанског шпанског; као породичном језику, који укључује кодове речи које одражавају породично окружење; као шаљивом језику (сличном другим јеврејским језицима) који омогућава избегавање друштвених табуа и цензуре, као додатном језику у случају лексичких празнина, углавном за речи које се односе на васпитавање деце.
\end{abstract}

Кључне речи: хакетија, jaquetia, интернет заједница, шпански Мароко, културе у контакту.

Haketia, the language of the Northern Moroccan Jews, is a language that has been repressed and asleep for many decades. Haketia is based mainly on Castilian Spanish with components of Maghrebi Arabic and Hebrew: it ceased being a living language at the beginning of the $20^{\text {th }}$ century, and it was condemned to extinction during the Spanish Protectorate of Northern Morocco between the years 1912 and 1956. During this period, in the attempt to erase any element that could create a barrier between them and the Spanish Protectorate, the Jews adopted Castilian customs as well as the language, consciously or unconsciously causing Haketia to disappear. The colonization process forced various ethnic groups to adopt elements from a culture that was different or in opposition to those of the 
local population, neither reflecting their needs nor their identities.In this process, a new identity was placed upon them a Western, European-Spanish identity that neutralized the uniqueness of their way of thinking as well as the rich culture that was embedded in the treasures of this culture. And in this process, the Haketia language also disappeared.

In this article, I will illustrate the comeback of Haketia and its uses in the continuing and ever-expanding circles of discourse as an anchor of identity among the Northern Moroccan Jews. I will examine the languages it is reflected in virtual arenas, social networking, and in social events that are based on the cities of origin of different communities or on the Haketia language itself - a phenomenon that was rarer in the past. This research is based on fieldwork and documentation that I have done among the Jews of Tetuan, the capital of northern Morocco, who have immigrated to Israel and other countries.

\section{A. The functions of the Haketia language today}

First, I examine the functions of the Haketia language as they are currently reflected among Jews around the world: Haketia is used today as a code language by Jews who live among Christian Castilian speakers. Thus, for example, the Spanish Jews of Northern Moroccan origin who live in Caracas, Venezuela, today, use their Haketia to teach basic words and expressions to the Ashkenazi Jews in order to distinguish the Jews as a whole from the Christians, and in order to enable intimate and discreet discourse in the proximity of Spanish Christian speakers.

Another function of Haketia is as an intimate language, including codes which reflect a family's way of life. There are traditional dishes that are still cooked and baked in different homes called by their Haketia names. For instance, cuajada- the traditional pie; ensaladacocha- a sweet or spicy pepper and tomato salad; panleves-Passover cookies made without flour; pescado en sharmila- a sour fish dish; adafina - a slow cooked dish kept on a hot plate throughout the Sabbath; oriza-traditional dish eaten on the Sabbath; letreas- thin noodles; cuscusú con ambrilla -a sweet couscous dish; fijuelas - fried thin dough made of flour and a large number of eggs, and many more. 


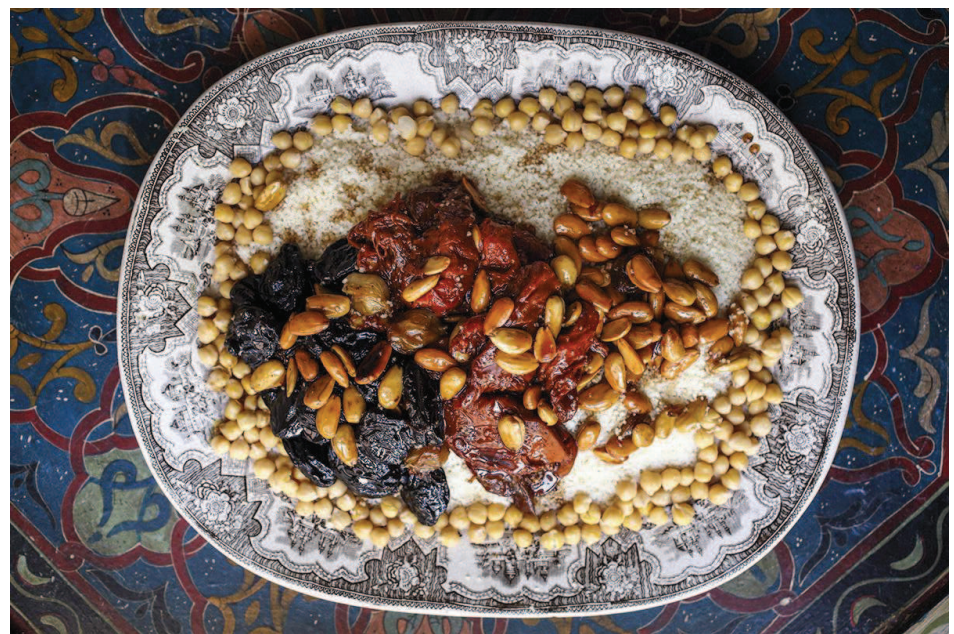

Cuscusúcon ambrilla (sweet couscous). Collection Pinto family.

The family language, peppered with Haketia, is also reflected in wishes and expressions of safety and well-being as well as greeting phrases that accompany the day-to-day life of the first and second generation of immigrants. Haketia expressions, such as No sea la falta de (in the memory of), mirey (my dear), miweno (my goodness), lo wenomio (oh my goodness), wo por mi se haga (oh, [the unlucky event] should be passed to me [i.e., released from you]), and so on, are built into the language used by the descendants of the immigrants, which include the children and grandchildren in Israel who do not have a command of the Spanish language.

Another function of the Haketia language, as in other Jewish languages, is humor. Humor makes it possible for speech that is better not used in the official spoken language to cross the lines of taboo and avoid social censure. For example, words that mock the weaker social classeslos de embasho- those who are of lesser status; for those who tend to believe in superstitions, or unamoraima to describe a crowd of Muslims. In Haketia, this kind of criticism is turned into something humorous.

Hakatia is also used in instances of lexical absence in Spanish or even in Hebrew, mainly in expressions and sayings used for educating children. Many words and expressions are used as a family "code" to determine the norms between filth and cleanliness, for example, "Don't be dirty and filthy"-no sershohonor "Don't dirty and don't ruin things"-no hacerfo- 
chiquina. Regarding weather conditions, a sentence that I have heard numerous times in many families - "abrígate bien porque esta cayendo una shaatá que te vas a llevar un tabardillo" (Dress warmly because it is raining cats and dogs, otherwise, you will catch a cold). Another example indicates the norms of gentleness and politeness opposed to vulgarity and egoism. For instance, No serjian is an expression used mainly when food is being served, instructing the child to serve himself in a measured way, to be considerate with the others at the table, to use self-control. Another expression heard frequently in families, jenia and safali, meaning "Don't be vulgar" is used to temper aggressiveness, loudness and lack of self-control.

The preceding examples show the main functions of Haketia in contemporary use. In the following, I map the activities that revived Haketia, and the strategies and practices that their speakers have adopted in the process of its revitalization.

\section{B. Strategies and practices in the revitalization process of Haketia}

\section{Level of activity of isolated instances, initiated by a few}

These are activities in the Sephardic Moroccan communities who use Haketia in several ways. For example, the enterprise of a woman from Tangier who organized an encounter where the noche de paños, the heena that is customary in Spanish Morocco, was reenacted. During the evening they sang various songs in Haketia. The ceremony itself underwent much transformation, but central to it is the use of Haketia in a most obvious and emphasized manner. The reenactment of the ceremony, taken from its original and authentic source, is an act that is meant to preserve the cultural memory and, in fact, to ensure its survival. The dress worn during the ceremony as well as the language used are part of the folkloric properties, in the terminology of Martin Skrydstrup (2012), that bring with them the identity of a people who seek opportunities that will give presence to their culture and by doing so, will rescue it. 


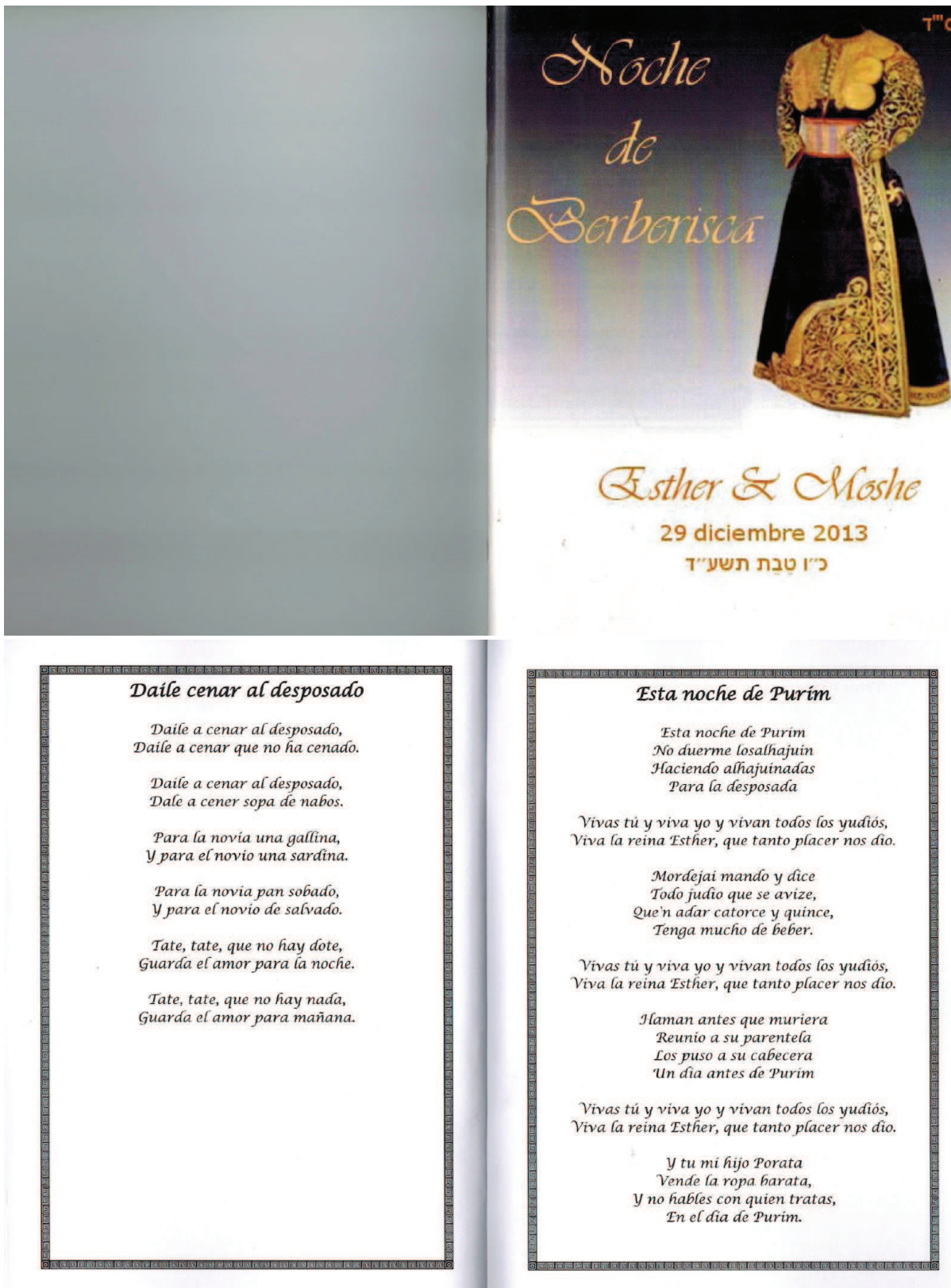

A folder with songs in Haketia that was given to guests at the ceremony of the «Noche de paños» 
Another example of individual initiatives are evenings in Israel arranged mainly for an audience who do not belong to the Haketic community but rather are Castilian speakers from Latin America looking for cultural and social activities. During those evenings, comedy sketches that the organizers themselves had written in Haketia were performed, illustrating the vitality of the language and the possibility of creating something new in doing so.

The presence of Haketia in recent years in collective community gatherings of this kind stand out against a background of years and generations of efforts to bury the language and testifies to an imagined community, in the terminology of Benedict Anderson (1991), created by a scattering of people all over the world trying to hold on to a culture that is being forgotten and that attempts to hang on to the slivers of memory of a language.

In women's meetings that have recently taken place in Israel, Haketia stands out as women write humoristic skits in Haketia and sing, one after the other, songs from the corpus of songs in Haketia that are familiar to them. In this way, they create an atmosphere full of humor and unity, singing and referring to their mothers and grandmothers who bequeathed to them the language as folkloric property that has not been obliterated from their memory, and extending the existing awareness - "the right place" from the vantage point of the immigrants.

Another dominant activity is that of Solly Lévy from Canada, an entertainer and actor who deserves a mention in this research. Solly Lévy has published various books in Haketia and has edited radio plays for Radio Sefarad based on anecdotes that describe everyday life common in Tetuan and Tangier, the places of his childhood. The anecdotes are written with great talent in the Haketia language, which he often translates into Spanish for the relevant audience. In this kind of artistic performance, there is also something in the reenactment that is not entirely authentic, mainly due to the compression of the common use of Haketia into a short unit for radio play time. The enactments of Solly Lévy present Haketia as a language that needs translation into Spanish, and Haketia is recognized as a language that can stand on its own, uses vocabulary that is completely different from Spanish, has different meanings for existing words, and is pronounced quite differently. However, the return to Haketia here, even if invented and artificial and even breaking with the original culture, affirms the possibilities of using Haketia as a language in itself. 
The presence of Haketia also appears in video clips on Youtube, filmed by a young boy, Aaron Israel, that relate the parables of La Fontaine translated into Haketia by his grandfather.These videos were filmed at different times in Aaron's life and present Haketia as the mother tongue of a grandparent who was fluent in the language and used it to communicate with his grandson.

\section{The presence of Haketia in today's Social Media}

The main website whose mission is to document and preserve the Haketia culture is the work of Alicia Sisso-Raz. This website is linked to a Facebook page that contains information, articles, pictures and links to the world of Haketia content. Alicia Sisso-Raz writes in Haketia, and the website acts as an umbrella for Haketia speakers in the world.

From the folklore point of view, the use of social media, especially Facebook, is research that requires a rigorous methodology. The use of Haketia in virtual information channels appears in various contexts, such as condolences, to report a happy event or convey a blessing, arousing nostalgia and the desire to share a common past. The appearance of Haketia on Facebook reveals a kind of underground web communication where different languages existing in parallel can be found in an open and equal world.

Samuel Bentolita \& Sam Buenavida

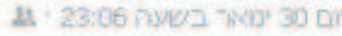

shrnulik tocayo que paso????? por D-OS te nos fuistes amigo?? que dolor tan grande enterarme de esta tristisima noticia, que ASHEM TODOPODEROSO te tenga entre IOS TZADICKM rey y que tus bendiciones lluevan sobre nosotros y eretz israel, shmulik los que te conocimos nunca olviaremos el don de buena persona que tuistes y dejaras un gran vacio en muchos corazones de amigos que te apreciamos, hasta luego hermano. hasta siempre BARUN DAYAN A EMET Z'L

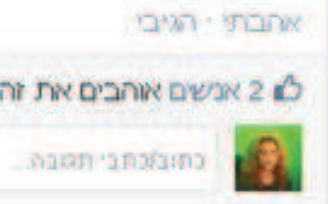


Estoy Halkeada !!!!!!!! Jaja

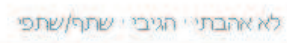

ש את ו-4 אחרים אוהבים את זהת.

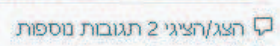

Porque??

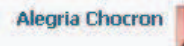

Porat

QUE HISISTES QUE ESTAN TAN CANSADA

mi prima parece que ya empezo a hacer pessah

$2 B$

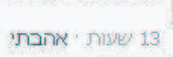

Doris Chocron

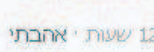

Alegria Chocron

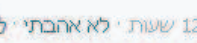

Ja ja no !!!! Con el calor que hace corriendo todo el día

Simy Zerrad Chocron

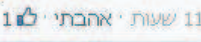

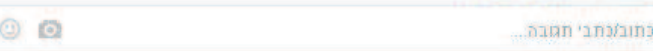

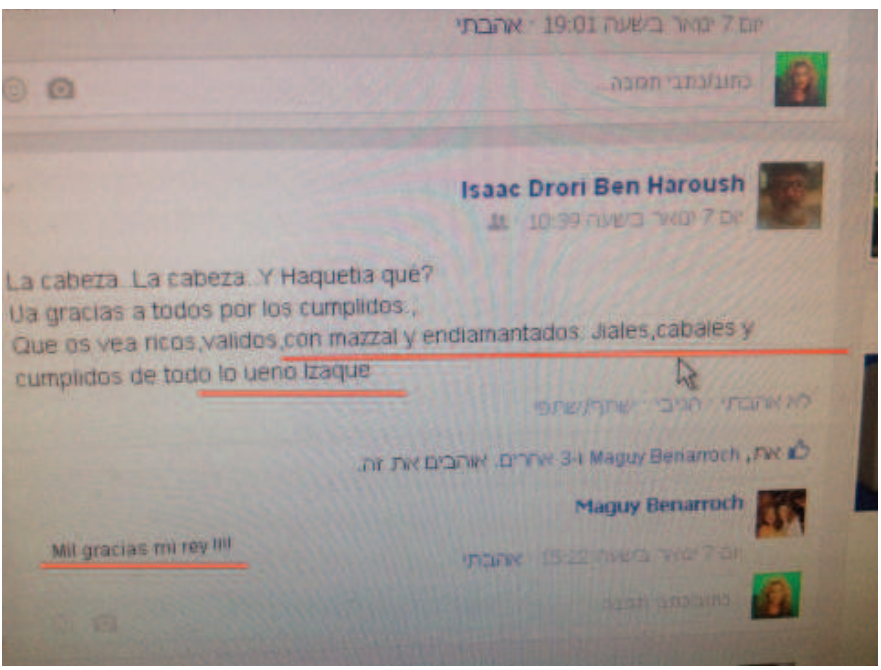

Posts and online entries in Haketia appearing on Facebook

\section{The Academic Level}

Activity on the academic level requires more expansive and reflexive research, but I would like to note that university centers for Ladino research have taken the Haketia language under their wing, encouraging 
research and granting an academic backing for university activities as well as for activities outside the university in an effort to stimulate interest in the wider community.

People of Spanish Moroccan origin, who once dropped Haketia from the list of cultural properties that defined them, felt urged, in this way, to come to university activities and identify through Haketia. After a cultural exile of many years, the Haketia community, which was keen to identify with their language, showed up in impressive numbers at university conferences to demonstrate their opposition to the suppression and loss of their cultural source. Finally, they had a place to which they could come.

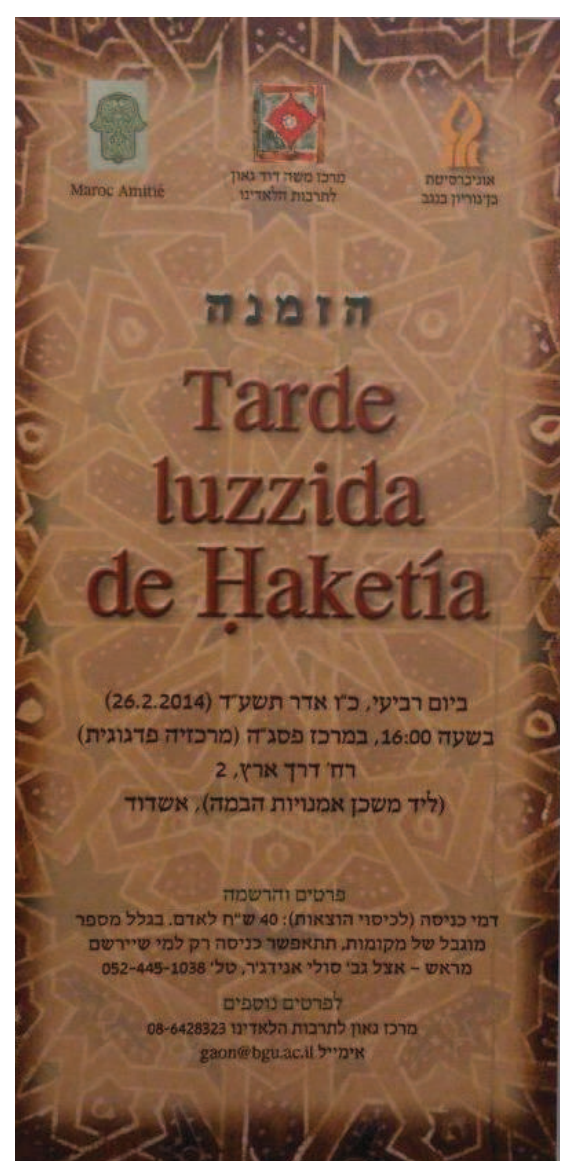

Invitation to a Haketia event, organized by Ben-Gurion University, Israel 


\section{The Timing of the revitalization of the Haketia language}

The question I would like to address is why, at this point in time, there has been a return to the Haketia language, as we have seen in the use of the language in different ways and the legitimization for such a diverse use of the language.

One of the reasons is conditioned by the cultural processes taking place in Israel today. We are witnessing a cultural movement of Sephardic Jews who would like to come closer to their traditions as well as to spread their culture. At a time when Sephardic Jews are no longer leaving their cultural identity at home, Haketia also bursts out of its private and reserved boundaries into the public domain and asks to establish an independent identity of its own with its own folkloric properties.

Haketia as a manifesting and unifying element. Folkloric properties that deteriorate symbolize a loss of culture (Skrydstrup, 2012). The use of the Haketia language is the most accessible and intimate way available to Northern Moroccan communities to preserve their cultural identity as a last resort. In the Social Networks, for example, the use of Haketia, even if it is minimal, is a manner of real communication and a way to let others know that you are one of them. Haketia acts as the catalyst to their joint past and a way to maintain continuity among anonymous entries on the network. One word identified as Haketia creates an immediate spark and intimacy that reminds them of their connection to the break that was created by the colonization in Morocco and the Moroccan emigration. The use of Haketia through this medium is done in order to find others in the community, and to give validation and presence to the uniqueness of the wider community allowing the different home and family languages to exist in a discourse that is at the same time anonymous and identified.

On the social networks, a person may reveal himself in various degrees of transparency. Moreover, the written content grants Haketia a more official appearance and reduces the stigma that Haketia speakers have attributed to it over the years.

Thus, in the social media, the use of written Haketia, mainly a spoken language, provides a new type of social discourse that has not been possible in previous decades. It can be seen used in various posts and on- 
line entries as openings to conversation and discourse where a word or two in Haketia acts like a fishing rod, drawing in responses of open and free expression, and works so that Haketia is "seen" in the community. While Facebook is not an official channel of information, it acts as an alternative forum that also suits Haketia as an alternative, non-official language.

The Movement for Research in Diverse Disciplines. The movement for research coming out of different universities in Israel and in the world, and whose researchers examine the historical, folkloric, linguistic, sociolinguistic and psycholinguistic aspects of Haketia, is a phenomenon that reflects a turn to the linguistic source as a sign of a culture-at-risk, and in danger of extinction and, therefore, the need to be documented. One should note that the last public organization of Spanish Moroccan Jews in Israel occurred in 1990 and 1991, under the auspices of Mabat, researched by the historian Aviad Moreno. The Mabat group set itself the goal of uniting the members of the community and giving expression to the Haketia language. In the last 25 years, no further organization has taken place, and only certain activities have taken place in the past few years in the university context.

An additional and important factor in the revival of Haketia in Israel is the increasing immigration of Jews from Venezuela. There, Haketia was preserved, as mentioned before, in a more dominant way as a practice intended to preserve Judaism, used as a strategy of cultural separation. The Jews of Venezuela encouraged each other to remain separate as was the case in meetings of women, and in other broader collective gatherings. These immigrants to Israel use Haketia frequently in the social network channels in a most obvious way.

The attempt to preserve Haketia on behalf of the culture. The preservation of Haketia as a cultural representation, containing the multicultural humor and spirit of the Northern Moroccan Jewish community on one hand, and of the traditional spirit of the Hebrew sources, on the other, is an attempt to preserve cultural values.

This language is the folkloric property that can save this unique culture from oblivion. Haketia is a cultural property, like other preserved cultural artifacts and ritual objects: ritual objects and the "noche de paños" dress (a Berberis wedding dress) mentioned above, one of the last and 
most important properties of the Northern Moroccan Jewish community which is a source of identity in the ceremony marking the transition from maidenhood to marriage- a wedding tradition that is also on the verge of oblivion. These properties create a deep feeling of belonging.

The attempt to preserve cultural values in recent times. The attempt to revive Haketia is therefore an attempt to hold onto the social and cultural values that characterized the spirit of the Northern Moroccan immigrants in the countries to which they immigrated as well as an attempt to preserve these values for the next generation before they became lost. It is an attempt to preserve the valuable habitus from an internal perspective, even if it is not the dominant habitus in the community's new homeland.

Preserving the "cultural capital" according to Pierre Bourdieu, is the commitment to maintain the strict social norms and hierarchy that have been maintained for hundreds of years in these communities. Linguists point out that the traditional pronunciation of the ancient Jewish texts after the expulsion of the Jews in 1492 has best been kept by the Jews of Tetuan (Maman, 1984). These Jewish communities attempted to keep their tradition, especially at this time when they feel that their traditions are being threatened. Moreover, the realization that their new homeland did not create a sense of home similar to the world they left behind gave birth to the desire to return to that sense of home in different ways, one of which has become returning to their old and neglected language, Haketia. It is not a sentimental act; on the contrary. the contemporary creative activity in the use of Haketia not only describes and deals with the old homeland, as related by Solly Lévy, but even interprets classics of the Grimm brothers to Haketia in a humorous way, or the La Fontaine fables, creating skits based on contemporary everyday life, using sharp and witty self-humor. This is the brave attempt of the few who have revealed themselves as Haketia speakers who have won enthusiastic and sincere feedback from their audiences.

Haketia has been defined by Yaakov Bentolila (1985), one of the major researchers of the field, as a language that "died from laughter." This description of Haketia reflects the words of Stuart Hall according to whom cultural identity cannot be reconstructed to exactly how it was before it was obliterated by a colonial context (1990). This is a heritage that has 
been created from memory, fantasy, narrative and myth. If the last stage in the life of a language includes the remaining expressions of humor and folklore, we can see that in the first stage of its revival is a new and original creation using humor. The next stage that we are looking for in the revitalization of this language is an original creation of the Haketia language that is not based on humor alone.A project to ensure this is in preparation.

Stages in the death and rebirth of Haketia

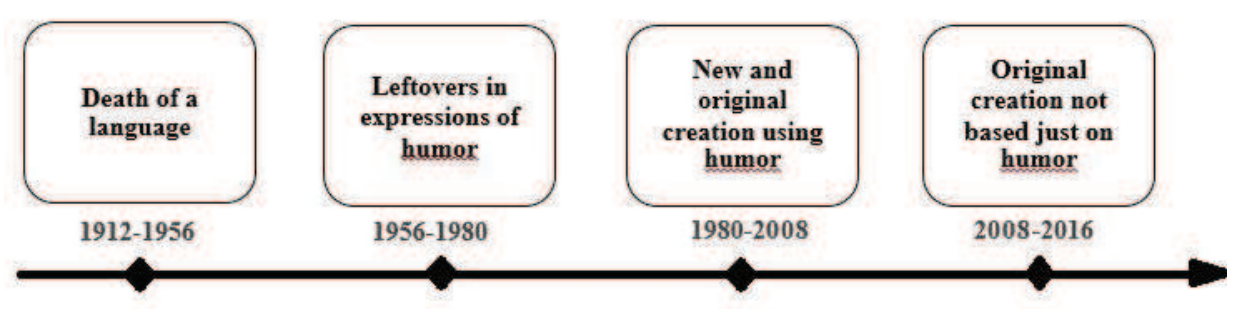

\section{Conclusion}

It is not my intention, at this point, to say that the Haketia language is spoken fluently among members of these communities, or that they use it frequently and freely. The comeback to Haketia is hesitant and perhaps even, in a way, invented and artificial. The Northern Moroccan Jews have difficulty in removing the Castilian wrapping, but today, more than in the past, we can see that the Jews of these communities allow their language to penetrate through the cracks and break away from the imitated identity they were forced to assume then, in that given period in Morocco.

\section{References:}

Aderet, Ofer, Coming back with Haketia: the Ladino stepsister comes back to speech, Haaretz, June $13^{\text {th }} 2014$ (Hebrew) - http://www.haaretz. co.il/news/education/.premium-1.2347891.

Anderson, Benedict, "Imagined Communities: Reflections on the Origin and Spread of Nationalism", London: Verso Books, revised edition, 1991.

Bénichou, Paul, Observaciones sobre el judeo-español de Marruecos, 
Nueva Revista de Filología Hispánica VII:3, 1945, pp. 209-258.

Benoliel, José, Dialecto judeo-hispano-marroquí o hakitía, Madrid, 1977. Bentolila, Yaakov., Le composanthébraïquedans le judéo-espagno lmarocain, Isaac Benabu \& Josef Sermoneta (eds.), Judeo-Romance Languages, Jerusalem, 1985, pp. 27-40.

Hall, Stuart, Cultural Identity and Diaspora, "Identity: Community, Culture, Difference" Ed. Jonathan Rutherford. London: Lawrence \&Wishart, 1990.

Hassán, Iacob. M., Testimonios antiguos de la jaquetía, La lengua y la literatura españolas en África, 1998, 147-169.

Juhas, Esther, Jewish Wardrobe from the Israel Museum Collection, Milan and Jerusalem, 2014.

Lévy,Solly, "Yahasrá: Escenas haquetiescas", E.D.I.J., Montréal, 1992.

Lévy, Solly, "El libro de Selomó”, Hebraica Ediciones, Madrid, 2008.

Maman, Aharon, Masorotha-qri Mišna: Praqim be-torat ha-hege, Masoret 1, 1984, pp. 51-120.

Moreno, Aviad, De-Westernizing Morocco: Pre-Migration Colonial History and the Ethnic-Oriented Self-Representation of Tangier's Natives in Israel, Journal of Fundazione CDEC, issue 4, November 2012.

Moreno, Aviad, "Europe from Morocco: The Minutes of the Leadership of Tangier's Jewish Community (the Junta), 1860-1864", Jerusalem: Ben-Zvi Institute, 2015.

Pinto-Abecasis, Nina, "The Peacock, the Ironed Man and the Half-Woman. Nicknames, humor and folklore in the day-to-day speech of Tetuan's Haketia-speaking Jews". Jerusalem: Ben-Zvi Institute, 2014.

Pinto-Abecasis, Nina, Towards the Inclusion of Nicknames in the Genres of Folklore: The Case of Tetuan's Jewish Community, Folklore, 2011, pp.135-154.

Skrydstrup, Martin, Cultural Property, in: "A Companion to Folklore", Regina F. Bendix, Galit Hasan-Rokem (Editors), Wiley-Blackwell, 2012, pp.520-536.

Vázquez, Ángel, "La vida perra de Juanita Narboni”, Cátedra, Madrid, 2005. 


\begin{abstract}
This article emphasizes the return to Haketia, the language of the Northern Moroccan Jews, and its use in broad circles of discourse as an anchor of identity among the Jews of Spanish Morocco. This return to the language is reflected in virtual spheres, social networks, social gatherings based on the city of origin or on the language itself - a phenomenon that was rarer in the past. The revival of Haketia in recent years invokes an "imagined community" (Anderson, 1991) of members spread out around the world, at the same time acting as an attempt to hold on to fragments of memory from the place they left. The focus of the paper is on Haketia's use as a secret language among Jews living with Christian speakers of Castilian Spanish; as a family language, which includes code words reflecting the family environment; as a humorous language (similar to other Jewish languages) enabling evasion of social taboos and censorship as well as a supplementary language in instances of lexical voids, mainly for words relating to the education of children.
\end{abstract}

Keywords: Haketia, Jaquetia, online community, Spanish Morocco, cultures in contact.

\title{
Biographical statement
}

DR. NINA PINTO-ABECASIS Nina Pinto Abecasis is a fellow researcher and teaches at Bar Ilan University, Salti Center for Ladino Studies and in the Open University, in Israel. Her research focuses on the study of folklore, as characteristic to the Jewish community in northern Morocco. Dr. Pinto Abecasis has published numerous articles on various subjects, such as: The relations among the various cultural groups in the former Spanish Protectorate in Morocco, the difficulties the Ladino-speaking immigrants have faced in Israel and the folklore among Israeli Arabs. Her book, The Peacock, The Ironed and the Half Woman was published in 2014 and has been awarded the Ben Zvi Institute prize for research on Jewish Communities. Her last publications:

- "The piropo as a bridge between cultures in Tetuan (northern Morocco)", Jerusalem Studies in Jewish Folklore 30, The Hebrew University of Jerusalem, 2016.(Hebrew) (in print)

- "Expresiones judeoespañolas en los relatos de vida de supervivientes griegos de la Shoa", Meah-Miscelánea de Estudio sÁrabes y Hebraicos, 2015, pp. 171-181. (Spanish) 
- "From Grandmother to Grandson - Judeo-Spanish Anecdotes in Israel Today: Emigration, Cultural Accommodation and Language Preservation", EJJS-European Journal of Jewish9, in a volume dedicated to the Sephardic Oral Literature, edited by Tamar Alexander, Brill, 2015, pp.100-119.

E-mail: pintonina@hotmail.com 